\title{
UJI EFEKTIVITAS EKSTRAK DAUN OLEANDER (Nerium oleander L.) SEBAGAI BIOLARVASIDA TERHADAP Aedes aegypti
}

\author{
Ayu Permatasari Putri ${ }^{1}$, Syalfinaf Manaf ${ }^{1}$, Milana Salim $^{2 *}$ \\ 1 Jurusan Biologi Fakultas MIPA Universitas Bengkulu \\ Jalan W.R. Supratman Kandang Limun 38371, Bengkulu, Indonesia \\ ${ }^{2}$ Balai Penelitian dan Pengembangan Kesehatan Baturaja \\ Jl. A.Yani KM.7 Kemelak Baturaja, Ogan Komering Ulu, 32111 Sumatera Selatan, Indonesia
}

\begin{abstract}
The use of herbal products is the best alternative in controlling mosquito populations. Many species of plants are known to have biological activities, producing secondary metabolites that could be potential as larvicides, one of them is oleander plant (Nerium oleander L.). This research was aim to determined the effectiveness of oleander leaf extract as biolarvicides againts Aedes aegypti larvae. This study used a completely randomized design (CRD) with seven treatments and four replications. It was used 25 Ae. aegypti larvae of Bengkulu strain, $3^{\text {rd }}$ instar as sample in each cup. The oleander leaf extract was made by using maseration methods with $96 \%$ ethanol as solvent and then concentrated by rotary evaporator. The concentration that used for effectiveness test obtained from preliminary tests: 50 ppm, 200 ppm, 350 ppm, 500 ppm, and 650 ppm. Positive control used a 1000 ppm of temephos solution and negative control was a distilled water. The effective concentration of oleander leaf extract determined with LC50 value and then analyzed by using analysis of variance (ANOVA). The result showed that the mortality percentage of Ae. aegypti larvae highest at $650 \mathrm{ppm}$. The results of variance analysis showed that there were significant differences between concentrations againts mortality of larvae at 127,938 ppm. Oleander leaf extract has the effectiveness as biolarvicides against Ae. aegypti larvae of Bengkulu strain.
\end{abstract}

Keywords: Leaf of Nerium oleander L., Aedes aegypti larvae., biolarvicide.

\section{THE EFFECTIVENESS TEST OF OLEANDER LEAF EXTRACT (Nerium oleander L.) AS BIOLARVICIDE AGAINST Aedes aegypti}

\begin{abstract}
Abstrak
Penggunaan produk herbal merupakan alternatif terbaik dalam mengendalikan populasi nyamuk. Banyak jenis tanaman diketahui memiliki aktivitas biologi, yakni menghasilkan metabolit sekunder yang berpotensi sebagai larvasida, salah satunya adalah tanaman oleander (Nerium oleander L.). Penelitian ini bertujuan untuk mengetahui efektivitas ekstrak daun oleander sebagai biolarvasida terhadap larva Aedes aegypti L. instar III. Penelitian ini menggunakan Rancangan Acak Lengkap (RAL) dengan tujuh perlakuan dan empat ulangan. Sampel penelitian sebanyak 25 larva Aedes aegypti instar III strain lokal Bengkulu per gelas uji. Pembuatan ekstrak daun oleander dilakukan dengan metode maserasi menggunakan etanol $96 \%$ yang dipekatkan dengan rotary evaporator. Konsentrasi ekstrak untuk uji efektivitas didapatkan dari hasil uji pendahuluan: 50 ppm, 200 ppm, 350 ppm, 500 ppm, dan 650 ppm. Kontrol positif menggunakan larutan temefos 1000 ppm dan kontrol negatif menggunakan akuades. Penentuan efektivitas konsentrasi ekstrak daun oleander dengan mencari nilai LC50. Selanjutnya data kematian larva Ae. aegypti dianalisis menggunakan analisis varian (ANOVA). Hasil penelitian menunjukkan bahwa persentase kematian larva terbanyak pada konsentrasi $650 \mathrm{ppm}$. Hasil analisis varian menunjukkan ada perbedaan nyata antar konsentrasi terhadap kematian larva dengan konsentrasi efektif 127,938 ppm. Ekstrak daun oleander efektif sebagai biolarvasida terhadap larva Ae.aegypti strain Bengkulu.
\end{abstract}


Kata Kunci: Daun Nerium oleander L., larva Aedes aegypti L., biolarvasida.

Naskah masuk: 23 Mei 2019; Review: 24 Juni 2019; Layak Terbit: 1 Desember 2019

*Alamat korespondensi penulis pertama: e-mail: milanwords@yahoo.co.id; Telp: (0735) 325303

\section{PENDAHULUAN}

Demam Berdarah Dengue (DBD) merupakan masalah kesehatan masyarakat di dunia, terutama di negara-negara tropis dan sub tropis termasuk di Indonesia. Penyakit ini merupakan salah satu penyakit menular yang mempengaruhi angka kematian anak dan dewasa serta dapat menurunkan produktivitas. Penyebaran demam berdarah meluas hingga ke 34 provinsi di Indonesia. ${ }^{1}$ Jumlah kasus DBD meningkat setiap tahunnya. Data dari Direktorat Pencegahan dan Pengendalian Penyakit Tular Vektor dan Zoonotik, Kementerian Kesehatan RI, mencatat jumlah penderita DBD di Indonesia pada tahun 2016 sebanyak 202.314 kasus dengan jumlah kematian sebanyak 1.593 jiwa. Kementerian Kesehatan RI menyebutkan pada tahun 2016 terjadi kejadian luar biasa (KLB) DBD, dilaporkan ada di 12 kabupaten dan 3 kota dari 11 provinsi di Indonesia. Dari 11 provinsi tersebut, diantaranya terdapat di Provinsi Bengkulu pada tahun 2016 ditemukan sebanyak 925 kasus dengan jumlah kematian 190 jiwa, sedangkan di tahun sebelumnya yakni tahun 2015 ditemukan sebanyak 467 kasus dengan jumlah kematian 93 jiwa. $^{2}$

Salah satu upaya pengendalian penyakit DBD adalah dengan mengurangi populasi vektor nyamuk Aedes aegypti, serta memutus kontak antara vektor dan manusia baik secara fisik, kimia, maupun biologi. Salah satunya adalah dengan menggunakan larvasida. Akan tetapi larvasida yang banyak digunakan saat ini merupakan larvasida kimia yang dapat mengakibatkan terjadinya pencemaran lingkungan. Selain itu, setiap organisme mempunyai kemampuan mengembangkan resistensi terhadap berbagai jenis pestisida, insektisida maupun larvasida yang akan semakin meningkat apabila penggunaan insektisida tersebut tidak dikendalikan.
Penggunaan insektisida sintetik juga dapat mengakibatkan terjadinya pencemaran lingkungan. Hal ini dikarenakan insektisida tertentu dapat tersimpan di dalam tanah selama bertahun-tahun, dapat merusak komposisi mikroba tanah, serta mengganggu ekosistem perairan. ${ }^{3}$

Sehubungan dengan hal tersebut, maka perlu dilakukan suatu usaha untuk mendapatkan insektisida alternatif dengan menggunakan bahan alami. Penggunaan produk herbal merupakan alternatif terbaik dalam mengendalikan populasi nyamuk. Banyak jenis tanaman diketahui memiliki aktivitas biologi, yakni menghasilkan metabolit sekunder secara rutin. Diantara metabolit sekunder itu, minyak atsiri dan kandungan sejenisnya telah banyak diteliti dalam rangka menemukan biopestisida baru. Beberapa diantaranya diketahui berpotensi sebagai insektisida. Penemuan mengenai preparasi herbal dan kandungan senyawa murni yang tidak merugikan organisme non target dan ramah lingkungan menjadi prioritas utama bagi peneliti untuk mengembangkan langkah-langkah alternatif pengendalian vektor. ${ }^{4}$

Diperkirakan ada sekitar 1.800 jenis tanaman yang mengandung pestisida nabati yang dapat digunakan untuk pengendalian hama. Di Indonesia, jenis tumbuhan penghasil pestisida nabati tersebar dalam 235 famili dengan 2.400 jenis tanaman. Walaupun hanya sekitar 10 ribu jenis metabolit sekunder yang telah teridentifikasi, jumlah bahan kimia pada tumbuhan yang potensial sebagai pestisida nabati diperkirakan mencapai 400 ribu jenis. ${ }^{5}$ Senyawa yang terkandung dalam tumbuhan dan diduga berfungsi sebagai insektisida diantaranya adalah golongan sianida, saponin, tanin, flavonoid, alkaloid, polifenol, steroid, dan minyak atsiri. $^{5}$ 
Salah satu tanaman yang diketahui memiliki kandungan metabolit sekunder dan berpotensi menjadi larvasida adalah tanaman oleander (Nerium oleander L.). Metabolit sekunder tersebut dilaporkan terdapat pada daunnya. Tanaman oleander mengandung senyawa metabolit sekunder seperti oleandrin, polifenol, dan triterpenoid. Tanaman oleander termasuk ke dalam famili Apocynaceae, yang diketahui memiliki daya racun, menghambat sistem respirasi, mempengaruhi sistem syaraf larva, dan dapat digunakan sebagai penolak serangga (repellent). ${ }^{6}$ Pemanfaatan ekstrak daun oleander untuk mengusir nyamuk masih kurang diketahui oleh masyarakat, meskipun masalah kesehatan yang disebabkan oleh nyamuk seperti DBD merupakan salah satu masalah serius yang harus diantisipasi. Bagian tanaman oleander yang dapat digunakan sebagai insektisida adalah akar, batang, kulit batang, daun dan bunga, akan tetapi yang paling sering digunakan adalah bagian daunnya dikarenakan pada daun oleander dilaporkan paling banyak mengandung oleandrin. ${ }^{7}$ Dengan hanya memangkas daunnya, maka tanaman dapat tetap hidup dan percabangan semakin banyak dan produksi daunpun semakin banyak.

Penelitian menggunakan ekstrak daun dan bunga Nerium oleander menunjukkan bahwa pada tanaman tersebut terkandung senyawa yang efektif seperti oleandrin dan berpengaruh terhadap nyamuk Anopheles stephensi, ${ }^{8}$ kemudian pada penelitian ekstrak etanol daun oleander terhadap larva nyamuk Culex quinquefasciatus diperoleh nilai LC50 197,97 ppm. $^{9}$ Penelitian menggunakan pelarut hexan pada bunga oleander terhadap larva nyamuk $C x$. quinquefasciatus hasilnya lebih tinggi dibandingkan rendaman/infus bunga oleander menggunakan pelarut air dengan nilai LC50 setelah 24 dan 48 jam masingmasing sebesar 102,54 dan 61,11 ppm. ${ }^{10}$ Beberapa penelitian tersebut menguatkan pernyataan bahwa tanaman oleander memiliki zat beracun bagi serangga. Tanaman oleander banyak ditemukan di Indonesia dan sering dijadikan sebagai tanaman hias, untuk itulah pada penelitian ini ingin dibuktikan manfaat lebih lanjut dari tanaman oleander sebagai biolarvasida terhadap Aedes aegypti.

\section{METODE}

Penelitian ini dilaksanakan di Laboratorium Fisiologi Hewan, Jurusan Biologi, Fakultas Matematika dan IImu Pengetahuan Alam, Universitas Bengkulu pada bulan Mei-Juli 2018. Rancangan yang digunakan adalah Rancangan Acak Lengkap (RAL) yang terdiri dari tujuh media uji, yakni lima media perlakuan konsentrasi ekstrak, satu perlakuan kontrol positif, dan satu perlakuan kontrol negatif. Jumlah pengulangan dihitung dengan menggunakan rumus Federer dan disepakati sebanyak empat ulangan. Sampel dalam penelitian ini adalah larva instar III Aedes aegypti hasil kolonisasi dari Laboratorium Entomologi Balai Litbang Kesehatan Baturaja, Kabupaten OKU, Sumatera Selatan. Sampel yang digunakan sebanyak 25 larva instar III tiap perlakuan dengan total sampel sebanyak 700 ekor larva. Daun oleander didapatkan dari tanaman oleander yang ditanam di Kelurahan Sukamerindu Kecamatan Sungai Serut, Kota Bengkulu.

Proses ekstraksi dimulai dengan menyiapkan bahan ekstrak berupa daun oleander sebanyak dua kilogram (berat basah) yang dicuci bersih lalu dikeringanginkan lebih kurang selama lima hari, selanjutnya diiris halus. Daun oleander yang sudah kering kemudian diblender hingga halus dan diayak sampai menjadi bubuk simplisia. Simplisia daun oleander tersebut diletakkan ke dalam labu erlenmeyer ukuran $2000 \mathrm{ml}$, kemudian etanol 96\% dimasukkan dengan perbandingan 1:2, selanjutnya diaduk-aduk dengan menggunakan batang pengaduk hingga homogen kemudian ditutup dengan alumunium foil sampai rapat. Maserasi untuk mendapatkan ekstrak daun oleander dilakukan selama $5 \times 24$ jam pada suhu kamar. Selanjutnya hasil maserasi (filtrat etanol) disaring dengan kertas saring dan dibebaskan dari pelarut dengan cara diuapkan menggunakan rotary evaporator. Setelah ekstrak mengental, kemudian ekstrak dimasukkan ke dalam gelas ukur dan diuapkan kembali pada waterbath bersuhu $60^{\circ} \mathrm{C}$ sampai didapatkan hasil akhir ekstrak berbentuk pasta. ${ }^{11}$ 
Larutan ekstrak diencerkan menjadi larutan $1 \%$, ini adalah larutan stok yang akan digunakan untuk membuat berbagai konsentrasi ekstrak. Dari larutan ekstrak $1 \%$ dibuat dosis ekstrak menggunakan rumus pengenceran $\mathrm{M} 1 . \mathrm{V} 1=\mathrm{M} 2 . \mathrm{V} 2$, dengan M1 = konsentrasi awal, V1 = volume larutan awal (yang dicari), M2 = konsentrasi akhir (yang diinginkan), V2 = volume larutan akhir $(200 \mathrm{ml})$. Konsentrasi ekstrak yang digunakan yakni $0,005 \%$ (50 ppm), 0,02\% (200 ppm), 0,035\% (350 ppm), 0,05\% (500 ppm), dan 0,065\% (650 ppm). Sebanyak 25 larva Aedes aegypti L instar III dimasukkan ke dalam gelas uji. Larutan stok temefos $1 \%$ dimasukkan ke dalam gelas uji sebagai kontrol positif, sedangkan akuades dimasukkan ke dalam gelas uji kontrol negatif. Total volume larutan dalam gelas uji menjadi $200 \mathrm{ml}$. Uji larvasida mengacu kepada metode dari $\mathrm{WHO} .^{12}$ Pada saat penelitian dilakukan pengukuran faktor abiotik meliputi suhu udara, kelembaban udara, suhu air, dan $\mathrm{pH}$ air.

Pengamatan terhadap kematian larva dilakukan setelah 24 jam perlakuan, dalam penelitian ini larva dikatakan mati jika tidak bergerak setelah disentuh beberapa kali dengan cara menyentuh bagian samping larva dengan jarum. Jumlah larva mati dihitung per gelas uji. Persentase kematian larva Aedes aegypti didapatkan setelah dilakukan korelasi menggunakan Rumus Abbott. Data hasil pengujian konsentrasi ekstrak daun oleander terhadap larva nyamuk Aedes aegypti L. instar III dianalisis menggunakan ANOVA dengan taraf signifikan $5 \%$ dan $1 \%$. Jika Fhitung > Ftabel, maka dilakukan uji lanjut Duncan untuk melihat perbedaan antar perlakuan.

\section{HASIL}

Berdasarkan hasil uji diketahui bahwa persentase kematian larva nyamuk Aedes aegypti semakin meningkat seiring dengan meningkatnya konsentrasi ekstrak daun Nerium oleander. Ekstrak $N$. oleander mampu menyebabkan kematian larva Aedes aegypti sebesar $42 \%$ pada konsentrasi terendah $50 \mathrm{ppm}$ dan mematikan $88 \%$ pada konsentrasi tertinggi 650 ppm. Hal ini membuktikan bahwa ekstrak daun $N$. oleander dengan berbagai variasi konsentrasi berpotensi dalam membunuh larva Aedes aegypti instar III. Pada kontrol negatif, tidak terdapat respon kematian sehingga tidak perlu dikoreksi dengan Rumus Abbott. Persentase mortalitas larva yang terpapar ekstrak daun oleander dan pelarut etanol $96 \%$ disajikan dalam Gambar 1.

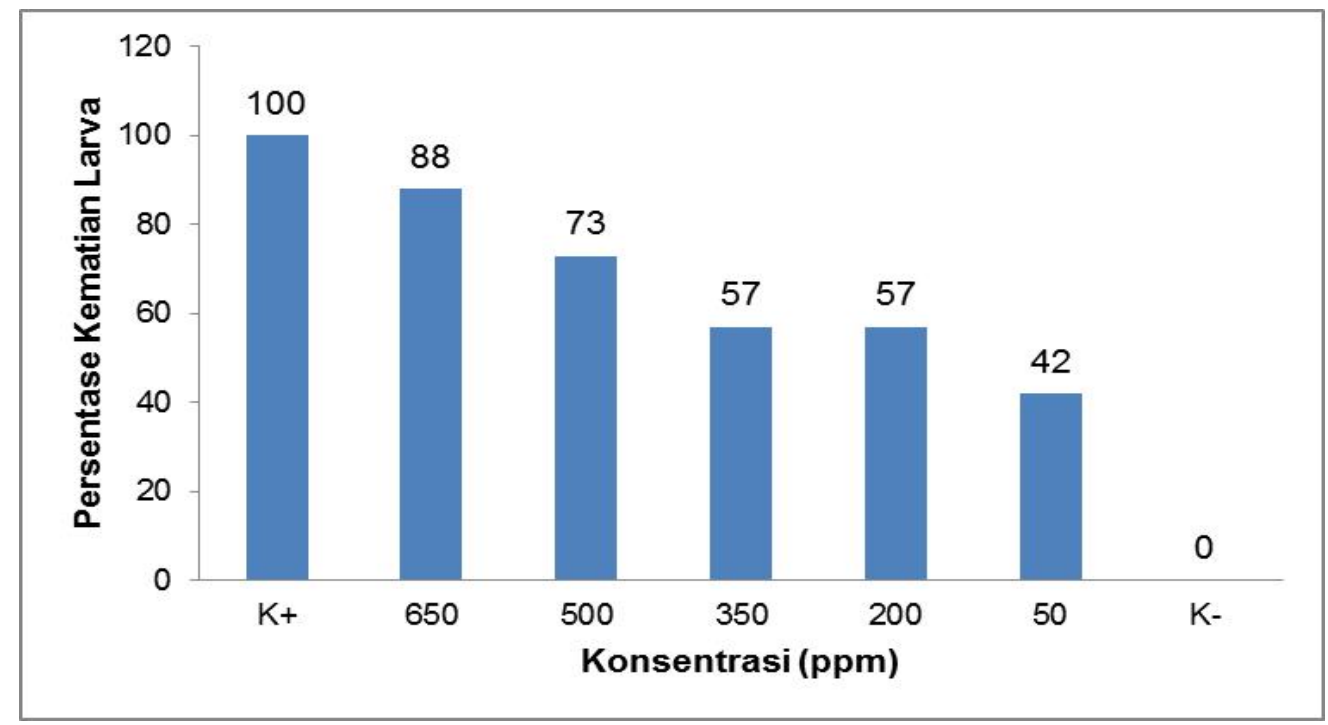

Gambar 1. Grafik hubungan antara perlakuan konsentrasi ekstrak Daun Oleander (Nerium oleander L.) dengan mortalitas larva uji

Pemberian konsentrasi ekstrak daun oleander menunjukkan perbedaan yang nyata terhadap kematian larva Ae. aegypti, dimana nilai Fhitung $>$ Ftabel pada taraf $5 \%$ 
dan $1 \%$ menunjukkan hasil yang sangat signifikan. Hal ini berarti kematian larva $A e$. aegypti disebabkan karena pengaruh pemberian ekstrak daun oleander.

Dari analisis ANOVA mortalitas Aedes aegypti strain lokal Bengkulu didapatkan perbedaan bermakna antar perlakuan (Fhitung>Ftabel), maka dilanjutkan dengan uji Duncan. Hasil uji Duncan dapat dilihat pada Tabel 2.

Tabel 1. Hasil analisis sidik ragam (ANOVA) mortalitas larva Aedes aegypti L. instar III strain lokal Bengkulu setelah 24 jam perlakuan

\begin{tabular}{lrrrrrr}
\hline $\begin{array}{c}\text { Sumber } \\
\text { Varian }\end{array}$ & DB & \multicolumn{1}{c}{ JK } & KT & Fhitung & $\begin{array}{c}\text { Ftabel } \\
(5 \%)\end{array}$ & $\begin{array}{c}\text { Ftabel } \\
(1 \%)\end{array}$ \\
\hline Perlakuan & 6 & 1623,429 & 270,5714 & $57,24937^{* *}$ & 2,572712 & 3,811725 \\
\hline Galat & 21 & 99,25 & 4,72619 & & & \\
\hline Total & 27 & 1722,679 & & & & \\
\hline Catatan : **berbeda nyata & \multicolumn{7}{c}{}
\end{tabular}

Tabel 2. Analisis uji lanjut Duncan terhadap selisih rata - rata mortalitas larva Aedes aegypti L. instar III strain lokal Bengkulu

\begin{tabular}{|c|c|c|c|c|c|c|c|c|c|}
\hline \multirow[b]{2}{*}{$\begin{array}{l}\text { Perlakuan } \\
\text { Konsentrasi }\end{array}$} & \multirow[b]{2}{*}{$\begin{array}{c}\text { Rata - } \\
\text { Rata }\end{array}$} & \multicolumn{7}{|c|}{ Selisih } & \multirow[b]{2}{*}{ Notasi } \\
\hline & & K- & $\begin{array}{r}50 \\
\mathrm{ppm}\end{array}$ & $\begin{array}{l}200 \\
\mathrm{ppm}\end{array}$ & $\begin{array}{r}350 \\
\mathrm{ppm}\end{array}$ & $\begin{array}{r}500 \\
\mathrm{Ppm}\end{array}$ & $\begin{array}{l}650 \\
\mathrm{ppm}\end{array}$ & $\mathrm{K}+$ & \\
\hline K- & 10 & 0 & & & & & & & $a$ \\
\hline $50 \mathrm{ppm}$ & 20,5 & 10,5 & 0 & & & & & & $b$ \\
\hline $200 \mathrm{ppm}$ & 24,25 & 14,25 & 3,75 & 0 & & & & & $\mathrm{bc}$ \\
\hline 350 ppm & 24,25 & 14,25 & 3,75 & 0 & 0 & & & & $\mathrm{bc}$ \\
\hline 500 ppm & 28,25 & 18,25 & 7,75 & 4 & 4 & 0 & & & $c d$ \\
\hline $650 \mathrm{ppm}$ & 32 & 22 & 11,5 & 7,75 & 7,75 & 3,75 & 0 & & $\mathrm{de}$ \\
\hline $\mathrm{K}+$ & 35 & 25 & 14,5 & 10,75 & 10,75 & 6,75 & 3 & 0 & e \\
\hline
\end{tabular}

Keterangan : Angka yang diikuti oleh huruf yang sama menunjukkan tidak berbeda nyata pada uji Duncan $\alpha 1 \%$.

Berdasarkan hasil dari uji Duncan pada Tabel 2, terlihat bahwa setiap konsentrasi ekstrak daun oleander berpengaruh terhadap mortalitas larva Aedes aegypti instar III. Pada Kontrol negatif, hasil uji statistik berbeda nyata dengan semua perlakuan konsentrasi ekstrak daun oleander dan kontrol positif. Perlakuan konsentrasi 650 ppm memiliki perbedaan yang nyata terhadap perlakuan konsentrasi lainnya dan kontrol negatif, akan tetapi tidak berbeda nyata dengan perlakuan konsentrasi ekstrak 500 ppm dan kontrol positif. Hal ini menunjukkan bahwa pada konsentrasi $650 \mathrm{ppm}$, ekstrak $N$. oleander sudah dapat membunuh lebih dari $50 \%$ total larva uji. Berdasarkan hasil uji jarak Duncan tersebut dapat diketahui bahwa konsentrasi ekstrak daun oleander $(N$. oleander) dengan pelarut etanol yang paling efektif dalam membunuh larva $A e$. aegypti terletak pada konsentrasi antara 200 ppm dan 350 ppm karena pada konsentrasi tersebut ekstrak sudah mampu membunuh larva Ae. aegypti lebih dari 50\% total seluruh larva uji yakni sebesar $57 \%$. Nilai LC50 ekstrak daun oleander dilihat dengan kurva persamaan regresi. Berdasarkan kurva persamaan regresi linier (Gambar 2.) didapatkan persamaan $\mathrm{y}=$ $2,354 x+0,04$. Dari persamaan tersebut ditentukan nilai LC50 untuk larva $A e$. aegypti strain lokal Bengkulu adalah $127,938 \mathrm{ppm}$ atau $0,012 \%$. Nilai LC50 tersebut menunjukkan bahwa biolarvasida ekstrak daun oleander pada konsentrasi $127,938 \mathrm{ppm}$ dapat membunuh $50 \%$ larva uji. Selain itu, persen kematian pada kontrol negatif (akuades) menunjukkan nilai $0 \%$ sehingga dapat dikatakan bahwa tidak ada 
faktor lain penyebab kematian larva kecuali kandungan senyawa kimia dari zat uji. Hasil ini menunjukkan bahwa ekstrak etanol daun oleander (Nerium oleander L.) bersifat toksik dan dapat dikembangkan sebagai biolarvasida.
Pengukuran faktor abiotik penting dilakukan sebagai data pendukung kehidupan nyamuk. Adapun hasil pengukuran faktor abiotik dapat dilihat pada Tabel 3.

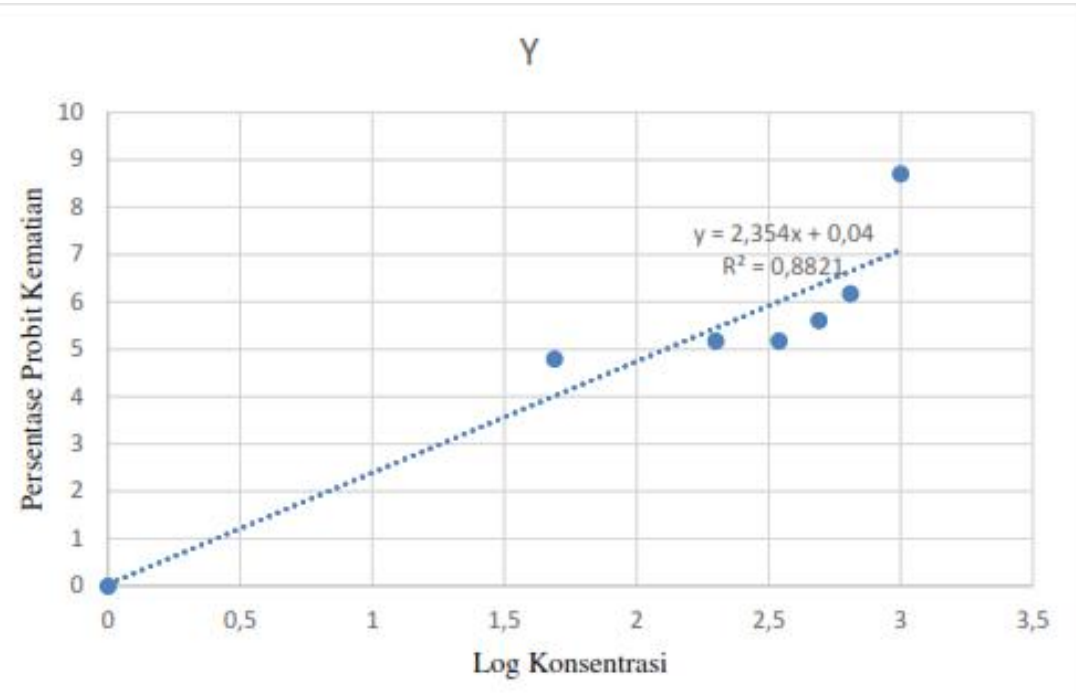

Gambar 12. Kurva persamaan regresi linier mortalitas larva Aedes aegypti

Tabel 3. Pengukuran faktor abiotik

\begin{tabular}{lll}
\hline No. & \multicolumn{1}{c}{ Faktor Abiotik } & Kisaran \\
\hline 1. & Suhu Udara $\left({ }^{\circ} \mathrm{C}\right)$ & $27-28$ \\
2. & Kelembaban Udara $(\%)$ & $65-69$ \\
3. & Suhu Air $\left({ }^{\circ} \mathrm{C}\right)$ & $25-28$ \\
4. & pH Air & 7 \\
\hline
\end{tabular}

Dari hasil pengukuran faktor abiotik larva Aedes aegypti instar III yang dipelihara selama masa uji di laboratorium didapatkan suhu udara, kelembaban udara, suhu air, dan $\mathrm{pH}$ air masih dalam batas toleransi bagi perkembangan larva nyamuk.

\section{BAHASAN}

Hasil uji efektivitas menunjukkan bahwa semua konsentrasi ekstrak menyebabkan kematian larva dengan persentase yang bervariasi. $\mathrm{Hal}$ ini membuktikan bahwa ekstrak daun $N$. oleander dengan berbagai variasi konsentrasi berpotensi dalam membunuh larva $A e$. aegypti instar III. Ekstrak daun oleander mengandung senyawa beracun yakni oleandrin dan adynerin yang termasuk ke dalam golongan alkaloid dari tanaman.
Alkaloid tersebut memiliki daya racun, menghambat sistem respirasi, mempengaruhi sistem syaraf larva, dan dapat digunakan sebagai penolak serangga. Tanaman oleander juga mengandung senyawa polifenol sebanyak $61 \%$ dan asam sinamat yang dapat digunakan sebagai antioksidan. ${ }^{7}$ Komponen alkaloid hampir terdeteksi pada semua tanaman yang diuji, disamping juga ditemukan komponen flavonoid lainnya yang berdampak langsung pada kehidupan serangga uji. Senyawa alkaloid ini sendiri berfungsi sebagai racun perut yang toksik ketika masuk ke dalam saluran pencernaan larva. ${ }^{11}$ Pembagian segmen pada tubuh larva tidak lagi tampak jelas karena telah mengalami kerusakan eksoskeleton. 
Pada kontrol negatif tidak ada larva uji yang mati. Hal ini berarti kematian larva Ae. aegypti disebabkan karena pengaruh pemberian ekstrak daun oleander, dan bukan disebabkan faktor lain. Senyawa aktif yang terkandung dalam larvasida nabati yang terakumulasi di dalam tubuh serangga akan berperan sebagai toksikan. Toksikan tersebut akan terdistribusi ke seluruh selsel tubuh melalui peredaran darah serangga (haemolimfa) yang mengakibatkan seluruh sirkulasi dalam tubuh akan terganggu. Apabila sekresi enzim terganggu, maka proses pencernaan makanan juga akan terganggu sehingga larva akan kekurangan energi dan lama kelamaan mengalami kematian. ${ }^{13}$

Hasil uji lanjut menunjukkan ada perbedaan bermakna antara variasi konsentrasi dengan mortalitas larva. Kematian larva nyamuk Ae. aegypti semakin meningkat seiring dengan meningkatnya konsentrasi ekstrak daun $N$. oleander. Sesuai dengan pendapat Prabowo, ${ }^{10}$ kematian pada perlakuan konsentrasi ekstrak menunjukkan bahwa dengan semakin meningkatnya konsentrasi, maka akan meningkatkan persentase kematian larva uji dikarenakan dengan meningkatnya konsentrasi yang digunakan, maka senyawa toksik bersifat racun yang masuk ke dalam tubuh larva uji akan terakumulasi semakin banyak sehingga mengakibatkan aktivitas hidup larva terganggu dan akhirnya menyebabkan kematian (mortalitas).

Pada konsentrasi ekstrak daun oleander 650 ppm menunjukkan hasil yang tidak berbeda dengan kematian pada kontrol positif. Ini dapat menjadi hasil alternatif larvasida potensial selain temefos yang selama ini digunakan. Hal ini juga dapat menjadi solusi untuk mengatasi resistensi terhadap temefos. Larvasida atau senyawa dikatakan bersifat toksik apabila memiliki nilai LC50 < 1000 ppm, sebaliknya apabila senyawa atau larvasida tersebut memiliki nilai LC50 > 1000 ppm, maka senyawa dikatakan tidak bersifat toksik dalam membunuh larva uji. ${ }^{14}$

Hasil pengukuran fisik saat pengujian menunjukkan nilai yang masih berada dalam kisaran optimal perkembangan nyamuk. Hal ini sesuai dengan penelitian Ridha yang menyatakan bahwa suhu udara rumah 20$30^{\circ} \mathrm{C}$ merupakan suhu optimum bagi perkembangan larva Ae. aegypti. Kelembaban rata-rata udara di 34 rumah di Kelurahan Loktabat Utara yaitu 67,3\% dan memiliki hubungan yang bermakna secara statistik $(p=0,037>0,05)$ untuk menunjang perkembangan larva. ${ }^{15}$ Diketahui bahwa larva tumbuh normal dalam air pada suhu optimal $25-35^{\circ} \mathrm{C}$. Derajat keasaman $(\mathrm{pH})$ air pemeliharaan dan $\mathrm{pH}$ air uji yakni 7 , hal tersebut sesuai dengan penelitian Lucia, larva $A$ e. aegypti dapat hidup pada air dengan $\mathrm{pH} 5,8-8,6 .{ }^{16}$

\section{KESIMPULAN}

1. Ekstrak daun oleander (Nerium oleander L.) memiliki efektivitas sebagai biolarvasida terhadap larva Aedes aegypti L instar III.

2. Konsentrasi letal ekstrak daun oleander (Nerium oleander L.) yang efektif dalam mematikan 50\% larva Aedes aegypti L instar III yakni 127,938 ppm.

\section{SARAN}

1. Perlu dilakukan penelitian lebih lanjut mengenai senyawa yang terkandung pada bagian tanaman oleander (Nerium oleander L.) lainnya seperti bunga, batang, dan akar yang nantinya dalam bentuk minyak atsirinya diharapkan dapat berfungsi sebagai biolarvasida.

2. Penelitian uji fitokimia dapat dilakukan terhadap senyawa yang terkandung dalam daun oleander (Nerium oleander L.) selain senyawa oleandrin, asam tanat (senyawa polifenol), dan triterpenoid yang dapat berfungsi sebagai biolarvasida dalam upaya mengendalikan larva nyamuk $A e$. aegypti.

3. Perlu penelitian lanjutan, untuk menilai toksisitas daun oleander terhadap hewan non target, misal ikan pada konsentrasi yang sama.

\section{KONTRIBUSI PENULIS}

Kontribusi penulis pada artikel ini yaitu, kontributor utama adalah MS dan kontributor anggota adalah APP dan SM. 


\section{UCAPAN TERIMA KASIH}

Ucapan terima kasih disampaikan kepada Dra. Helmiyetti, M.S dan Dra. Rochmah Supriati, M.Sc yang telah banyak memberikan arahan dan masukan dalam penyempurnaan penelitian ini. Kepada Dr. Rizwar, M.S. dan seluruh dosen Jurusan Biologi FMIPA atas ilmu pengetahuan, pelajaran dan pengalaman selama penulis menuntut ilmu di Universitas Bengkulu. Seluruh peneliti dan staff di Laboratorium Entomologi Balai Litbangkes Baturaja yang telah banyak membantu, membimbing, dan memberikan ilmu pengetahuannya sehingga dapat terselesaikannya penelitian ini.

\section{DAFTAR PUSTAKA}

1. Kementerian Kesehatan RI. Profil Kesehatan Indonesia 2015. Jakarta: Kementerian Kesehatan Republik Indonesia; 2016. doi:351.077 Ind

2. Kementerian Kesehatan RI. Profil Kesehatan Indonesia Tahun 2016. Jakarta: Kementerian Kesehatan Republik Indonesia; 2017.

3. Aji A, Maulinda L, Amin S. Isolasi nikotin dari puntung rokok sebagai insektisida. J Teknol Kim. 2015;1(Mei):100-120.

4. Kishore N, Mishra BB, Tiwari VK, Tripathi V, Lall N. Natural products as leads to potential mosquitocides. Phytochem Rev. 2013:1-41. doi:10.1007/s11101-013-9316-2

5. Saenong MS. Tumbuhan Indonesia potensial sebagai insektisida nabati untuk mengendalikan hama kumbang bubuk jagung (Sitophilus sp). J Litbang Pertan. 2016;35(3):131-142. doi:10.21082/jp3.v35n3.2016.p131142

6. Goktas O, Mammadov R, Duru ME, Ozen E, Colak AM. Application of extracts from the poisonous plant, Nerium Oleander L., as a wood preservative. African $J$ Biotechnol. 2007;6(September):2000-2003. http://www.academicjournals.org/AJB.

7. Siham L, Saida O, Moha T, Nadia S, Hakima A. Chemical analysis and antioxidant activity of "Nerium
Oleander" leaves. J Biol Sci. 2014;14(1):1-7. doi:10.3844/ojbsci.2014.1.7

8. Mohammad Reza Fakoorziba, Djaefar M, Moemenbellah-Fard, Azizi K, Mokhtari F. Mosquitocidal efficacy of medicinal plant, Nerium oleander (Apocynaceae), leaf and flower extracts against malaria vector, Anopheles stephensi Liston (Diptera: Culicidae) larvae. Asian Pacific J Trop Dis. $\quad$ 2015;5(1):33-37. doi:https://doi.org/10.1016/S22221808(14)60623-X

9. Komalamisra $\mathrm{N}$, Trongtokit $\mathrm{Y}$, Rongsriyam $\mathrm{Y}$, Apiwathnasorn $\mathrm{C}$. Screening for larvicidal activity in some Thai plants against four mosquito vector species. Southeast Asian J Trop Med Public Health. 2005;36(6):1412-1422.

10. Raveen R, Kamakshi KT, Deepa M, Arivoli S, Tennyson S. Larvicidal activity of Nerium oleander $\mathrm{L}$. (Apocynaceae) flower extracts against Culex quinquefasciatus Say (Diptera: Culicidae). Int $J$ Mosq Res. 2014;1(1):38-42.

11. Prabowo $\mathrm{H}$. Pengaruh ekstrak bunga oleander (Nerium oleander L.) terhadap mortalitas hama tanaman jarak pagar Seleno (Thrips rubrocinctus Giard). In: Seminar Nasional Biologi, Fakultas Biologi, Universitas Gadjah Mada. Yogyakarta; 2010.

12. World Health Organization. Guidelines for Laboratory and Field Testing of Mosquito Larvicides. CDC, WHOPES; 2005.

http://apps.who.int/iris/bitstream/1066 5/69101/1/WHO_CDS_WHOPES_GC DPP_2005.13.pdf.

13. Ningsih TU, Haryono T. Pengaruh filtrat umbi gadung, daun sirsak dan herba anting-anting terhadap mortalitas larva Spodoptera litura. LenteraBio. $\quad 2011 ; 2(1): 33-36$. http://ejournal.unesa.ac.id/index.php/l enterabio.

14. Salim M, Sulistyaningrum N, Yahya, Isnawati A, Sitorus H, Ni'mah T. 
Karakterisasi simplisia dan ekstrak kulit buah duku (Lansium domesticum Corr) dari Provinsi Sumatera Selatan dan Jambi. J Kefarmasian Indones. 2016;6(2):117-128.

15. Ridha MR, Rahayu N, Rosvita NA, Setyaningtyas DE. Hubungan kondisi lingkungan dan kontainer dengan keberadaan jentik nyamuk Aedes aegypti di daerah endemis demam berdarah dengue di Kota Banjarbaru.
J Buski. 2013;4(3):133-137.

16. Yogyana L, Ibrahim E, Bintara AB. Hubungan karakteristik lingkungan kimia dan biologi dengan keberadaan larva Aedes aegypti di wilayah endemis DBD di Kelurahan KassiKassi Kecamatan Rappocini Kota Makasar Tahun 2013. 2013:1-11. https://core.ac.uk/download/pdf/25490 961.pdf. 